\title{
Primary succession on a seasonal tropical rocky shore: the relative roles of spatial heterogeneity and herbivory
}

\author{
Gray A. Williams ${ }^{1, *}$, Mark S. Davies ${ }^{2}$, Sanjay Nagarkar ${ }^{1}$ \\ ${ }^{1}$ Department of Ecology and Biodiversity, The Swire Institute of Marine Science, The University of Hong Kong, \\ Pokfulan Road, Hong Kong \\ ${ }^{2}$ Ecology Centre, University of Sunderland, Sunderland SR1 3SD, United Kingdom
}

\begin{abstract}
Hong Kong is within the tropics and has a seasonal climate. In winter, shores support patches of ephemeral macroalgae and areas of seemingly bare rock close to crevices where molluscan herbivores are abundant. Using a factorial design of herbivore exclusions in areas far and close to crevices, the development of algal assemblages was monitored in mid-shore, cleared areas, in winter. To estimate the role of herbivore mucus deposition, half the treatments received a mucus application. Algal development was estimated from macroalgal and biofilm development and chlorophyll a levels. In all areas, biofilms (diatoms, unicellular cyanobacteria) developed rapidly in herbivore exclusions followed by ephemeral macroalgae (Enteromorpha spp. and Porphyra suborbiculata). In herbivore access treatments, however, the algal assemblage was influenced by treatment location; few macroalgae developed in areas close to crevices, and the rock was dominated by cyanobacteria. A negative relationship between macroalgae and biofilms suggested that ephemeral algae were competitively dominant. In areas distant from herbivore refuges, ephemeral macroalgae did develop, illustrating that the effectiveness of molluscan herbivores was limited to 50 to $100 \mathrm{~cm}$ from these refuges. The absence of large herbivorous fish, and the sparse numbers of herbivorous crabs at this site, means that algae can achieve a spatial escape from consumption, and where this occurs competition between producers is important in assemblage development. Mucus appeared to play a limited role, only sometimes stimulating initial stages of unicellular cyanobacteria and macroalgae. With the onset of summer, macroalgae died back, and rock space became available for colonization. Unicellular cyanobacteria developed rapidly but were replaced in all treatments by the encrusting macroalga, Hapalospongidion gelatinosum, which dominated treatments until the end of the experiment. On seasonal, tropical shores processes influencing community structure can, therefore, be temporally variable and their relative importance, even at the same shore level, can change with season.
\end{abstract}

KEY WORDS: Biofilm · Cyanobacteria · Herbivory · Hong Kong · Mucus · Spatial heterogeneity · Succession · Tropical rocky shore

\section{INTRODUCTION}

Herbivores influence the distribution, diversity and abundance of macroalgal assemblages on shores of varying exposures world-wide (reviewed by Hawkins \& Hartnoll 1983, Vadas 1985). The direct impacts of herbivores are dependant on a number of factors, of

*E-mail: hrsbwga@hkucc.hku.hk which environmental conditions have a great influence in moderating algal-herbivore interactions (Underwood \& Jernakoff 1981, Underwood 1985). Herbivores also influence the biomass and diversity of microalgal assemblages (Nicotri 1977) although studies on this role are scarce. The physical act of grazing is not, however, the sole impact of herbivores as deposition of mucus can trap and stimulate microalgal growth (see Davies \& Hawkins 1998 for review), and herbivore excretion may fertilize algal growth (Carpenter 1986) and aid dispersal (Santelices \& Ugarte 1987). 
Herbivores are rarely evenly distributed, and as a consequence, predation pressure is spatially and temporally variable resulting in density effects on the prey species (Underwood et al. 1983, Hartnoll \& Hawkins 1985). Variation in herbivore density within a shore can influence spatial patterns of algal abundance resulting in patches of different species which have escaped grazing, are stimulated by low or high grazing pressure, or often bare areas of rock (commonly referred to as halos) within areas of high algal abundance. Such halos are often focused on spatial refuges in the rock surface where herbivores aggregate when at rest, and leave to forage (Hawkins \& Hartnoll 1983, Chapman \& Underwood 1992).

On some tropical shores, where environmental conditions are relatively constant, species distribution patterns and abundance are very patchy (e.g. the Bay of Panama, Lubchenco et al. 1984) and set by predation pressure from a diversity of consumers in the low-shore and availability of refuges from thermal and desiccation stress in the mid-shore (Menge \& Lubchenco 1981, Garrity 1984, Menge et al. 1985, 1986). As a result, species are found in cracks and crevices which provide shelter from predators and a relatively cool or damp habitat (reviewed by Brosnan 1992). The distribution of these habitats, and the limited movement of species from these areas can cause a patchy mosaic of species (Levings \& Garrity 1983).

Spatial heterogeneity can, therefore, have direct (species distribution patterns) and indirect (impact of consumers, especially herbivores) influences on community dynamics on tropical rocky shores. On a small scale, near refuges, consumer pressure is likely to have a strong influence, as these areas would be heavily cropped but areas further away would receive little influence. High grazing pressure may also have positive effects, stimulating algal production (Carpenter 1986) and indirectly enhancing microalgal and bacterial growth (Davies \& Hawkins 1998), which may increase primary production. There may, therefore, be an interaction between grazing removing algae and bacteria, and a possible influence of enhanced productivity, especially in the epilithic biofilm, which on tropical shores is mainly composed of cyanobacteria (Nagarkar \& Williams 1997, 1999, Nagarkar 1998a,b).

The relative importance of predation/herbivory has been hypothesized to vary with environmental conditions (Brosnan 1992), following models proposed by Menge \& Sutherland $(1976,1987)$. In physically harsh environments, predation is assumed to be unimportant, whereas in more benign environments herbivory plays a strong role in community structure. The importance of herbivory may also vary temporally where shores experience both benign and harsh environments in different seasons (Brosnan 1992). Such is the case for many seasonal, tropical shores with monsoonal climates (e.g. Hong Kong, India and West Africa). Hot summers kill foliose macroalgae and invertebrates, freeing primary space, and mobile species retreat lower on the shore and take refuge in crevices (Lawson 1966, John et al. 1992, Kaehler \& Williams 1996, Nagarkar \& Williams 1999). In winter, conditions ameliorate, macroalgae flourish and mobile invertebrates extend their vertical range and their foraging periods (Banaimoon 1988, Murthy et al. 1989, Williams $\&$ Morritt 1995). The structuring role of spatial heterogeneity and environmental harshness can, therefore, vary temporally on such seasonal tropical shores.

This paper investigates small scale (metres) spatial patterns of macroalgal and biofilm distribution relative to herbivore refuges on a seasonal, tropical, rocky shore. Spatial patterns of succession were monitored on cleared rock surfaces in close proximity to crevices and areas distant from these habitats. Variation in succession in these areas may be the result of a location effect (i.e. algal development being influenced by the habitat itself) or an interaction between the crevices and grazing pressure, associated with the fact that grazers seek refuge in these areas and forage over a limited range around these crevices. This was tested using herbivore exclusions in areas close to and far away from crevices, where the interaction between these factors would elucidate the processes affecting algal distribution. Direct and indirect impacts of herbivores on macroalgal and biofilm assemblages were tested by allowing herbivores to leave mucus trails in herbivore exclusions in a factorial design with the location and exclusion treatments. Temporal changes in algal development in these treatments were followed between winter and summer (i.e. from benign to harsh conditions).

\section{MATERIALS AND METHODS}

Study site and timing. Experiments were conducted on a moderately exposed, gently sloping, granodiorite shore at Cape d'Aguilar, Hong Kong $\left(22^{\circ} 20^{\prime} \mathrm{N}, 114^{\circ}\right.$ $\left.10^{\prime} \mathrm{E}\right)$. Maximum tidal range at this site is $2.5 \mathrm{~m}$ and tides are predominantly mixed semi-diurnal (Morton et al. 1996). The experimental area $\left(\sim 40 \mathrm{~m}^{2}\right.$, between 1.50 and $1.75 \mathrm{~m}$ above Chart Datum) was subdivided into a grid and $50 \times 50 \mathrm{~cm}$, double-strung 100-point quadrats were sequentially placed to assess macroalgal and herbivore distribution.

Experiments were initiated in April 1995 (end of winter) and terminated in mid-July 1995 (summer). Hong Kong has a hot and wet summer (July to September; mean surface seawater temperature $\sim 27^{\circ} \mathrm{C}$, mean air temperature $\sim 28^{\circ} \mathrm{C}$, maximum air temperature $=36^{\circ} \mathrm{C}$, rock temperatures can exceed $50^{\circ} \mathrm{C}$ ) and a cool and 
dry winter (December to March; mean water temperature $\sim 17^{\circ} \mathrm{C}$, mean air temperature $\sim 15^{\circ} \mathrm{C}$ ). The period from April to May represents the transition from winter to summer. Air temperatures in April 1995 were relatively cool (mean $\sim 26^{\circ} \mathrm{C}$ ) but increased during the experiment and after $\sim 40 \mathrm{~d}$ (mid-May) reached $\sim 30^{\circ} \mathrm{C}$ (maximum temperature $=33.6^{\circ} \mathrm{C}$ ). Tidal height also varied temporally, the height of low water tides decreasing towards summer (by $\sim 0.4 \mathrm{~m}$ ).

Manipulative experiments. A 4-factor experiment was used to investigate whether the pattern of macroalgal distribution was a result of herbivore grazing, mucus deposition by herbivores, a location effect or interactions between these main treatments. Ten areas (Areas) of the shore were selected, which either had a high cover of erect macroalgae ( $>70 \%$ cover) and were $>1 \mathrm{~m}$ away from a crevice (designated + A [Algae] areas, $\mathrm{n}=5$ ) or a relatively sparse cover $(<20 \%$ cover $)$ and within $50 \mathrm{~cm}$ of a crevice (designated $-\mathrm{A}$ areas, $\mathrm{n}=5$ ). This treatment, therefore, accounted for both variation in algal cover and distance from crevices as these influences were linked. Within these areas molluscan herbivores were either excluded, or allowed access to $23 \times 23 \mathrm{~cm}$ areas. Completely fenced areas ( $\mathrm{H}$ [herbivores]), using $25 \times 25 \mathrm{~cm}(1 \mathrm{~cm}$ edge $)$ wire mesh $(5 \times 5 \mathrm{~mm})$ fences, prevented molluscs from entering the experimental areas; however, fish and herbivorous crabs could potentially enter these areas. In herbivore access areas $(+\mathrm{H})$, a partial fence (2 L-shaped corners) was used to control for possible procedural effects. Two of each treatment were randomly established in each of the algal areas and in 1 of each (randomly assigned) herbivores were allowed to lay mucus trails (see below). This treatment, in herbivore exclusions, allowed the influence of grazing and mucus deposition to be separated experimentally. The full experimental design included 2 herbivore treatments and 2 mucus treatments in locations with dense and sparse algal cover replicated in 5 areas $\left(\sum \mathrm{n}=\right.$ $2 \times 2 \times 2 \times 5=40$ ). This experimental design did not include a natural control treatment (i.e. open plots which allow herbivores access) which may have limited the generality of the findings. Partial fence treatments, in similar manipulations on Hong Kong's moderately exposed shores, proved not significantly different to unfenced, open areas, suggesting that results from this treatment are comparable to unmanipulated areas (Williams 1994). Rock surfaces were scraped clean and then blowtorched to white hot on 3 consecutive days prior to the initiation of the experiment.

Mucus application. To achieve a coating of mucus (+M) 4 Cellana toreuma, 10 Nerita albicilla and 20 Monodonta labio (the most abundant species, Table 1) were stimulated, by spraying with seawater, to crawl over the experimental surfaces for $15 \mathrm{~min}$, at approximately weekly intervals. The molluscs grazed slightly upon these treatments whilst moving; however, this effect is thought to have been minimal. Treatments which did not receive a mucus application $(-\mathrm{M})$ were also sprayed with seawater as a procedural control. Individual molluscs were used on 2 experimental areas and then replaced with new ones.

Pedal mucus production was estimated by stimulating molluscs to crawl over $25 \times 25 \mathrm{~cm}$ glass plates in the laboratory. After $15 \mathrm{~min}$, the individuals were removed, the mucus was scraped from the glass and first wet and then dry weighed $\left(70^{\circ} \mathrm{C}\right.$ to constant weight). An average of $0.0132 \mathrm{~g}$ dry weight $\left( \pm 1.06 \times 10^{-3} \mathrm{SD}, \mathrm{n}=4\right)$ was laid down by the herbivores.

Macroalgal and biofilm abundance. To investigate changes in macroalgal (i.e. visual) abundance, the percentage cover was scored using a $23 \times 23 \mathrm{~cm}$, 100point, double-strung quadrat at approximately 7 to $14 \mathrm{~d}$ intervals (depending on tidal conditions). Macroalgae were scored to species, except the turfs of green algae which were scored as 'green turfs' (primarily Enteromorpha spp.). A change in the rock colour (usually a green colour) was scored as a 'biofilm'.

Rock chips $\left(\sim 1.5 \mathrm{~cm}^{2}\right)$ were also removed, fixed in $2.5 \%$ (v/v) glutaraldehyde, air-dried, gold-palladium coated and viewed under the scanning electron microscope (SEM, Leica Cambridge S440). The percentage cover of biofilm species was scored from 10 random fields of view at fixed magnification (500×) using a 100point grid (see Nagarkar \& Williams 1997). Species were scored in 9 broad groups: diatoms; sporelings of Porphyra subaorbiculata, Enteromorpha spp. (macroalgae); unicellular cyanobacteria; Phormidium spp.; Lyngbya spp.; Calothrix spp.; and the encrusting algae Hapalospongidion gelatinosum and Hildenbrandia rubra. Only abundant groups (>5\% cover at each time period) were statistically analyzed.

Changes in overall algal biomass (macroalgae and biofilm) were assessed by chlorophyll a (chl a) analysis of rock chips $\left(\sim 2.5 \mathrm{~cm}^{2}\right)$ taken from each treatment, again at 7 to $14 \mathrm{~d}$ intervals and extracted using hot methanol (see Nagarkar \& Williams 1997). Areas from which rock chips were removed remained visible in the treatments and accounted for $<10 \%$ of individual areas at the end of the experiment. These areas were not scored during the percentage cover estimates, nor were subsequent rock chips taken from the same areas.

Statistical analysis. A 4-way, mixed model, analysis of variance (ANOVA) was used to investigate variation in percentage cover of visible algae, and the biofilm scored under the SEM. Herbivore exclusion or access $(-$ or $+\mathrm{H})$ and mucus application (+ or $-\mathrm{M})$ were fixed, orthogonal effects. The treatment with sparse algal cover $(-\mathrm{A}$, close to crevices) and high algal cover $(+\mathrm{A}$, far from crevices) was also a fixed effect. A fourth factor, the individual areas (Areas, $\mathrm{n}=10$ ), was random 
and nested within the algal cover treatment. The use of unreplicated treatments within specific locations (algal areas) means that the analysis cannot detect smallscale changes in the effects of herbivores and mucus coating in the individual areas (interactions with the term Areas [A]). Time was not included as a factor as temporal readings were non-independent. The percentage cover data were arc-sine transformed prior to analysis and Student-Neumann-Keuls tests used to separate significant means (Underwood 1997). As rock chips were also repeatedly sampled from the same treatment for chl a analysis, these data are also temporally non-independent. Chlorophyll data were, therefore, only analysed for the time of peak levels $(t=32 \mathrm{~d}$, 18 May). Chl a data failed Cochran's test for homo-

(a) Macroalgal cover

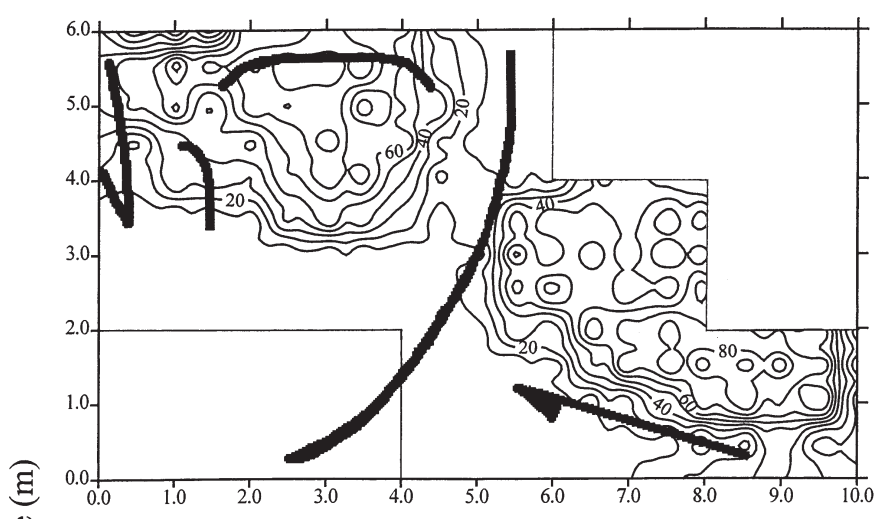

(b) Herbivore density

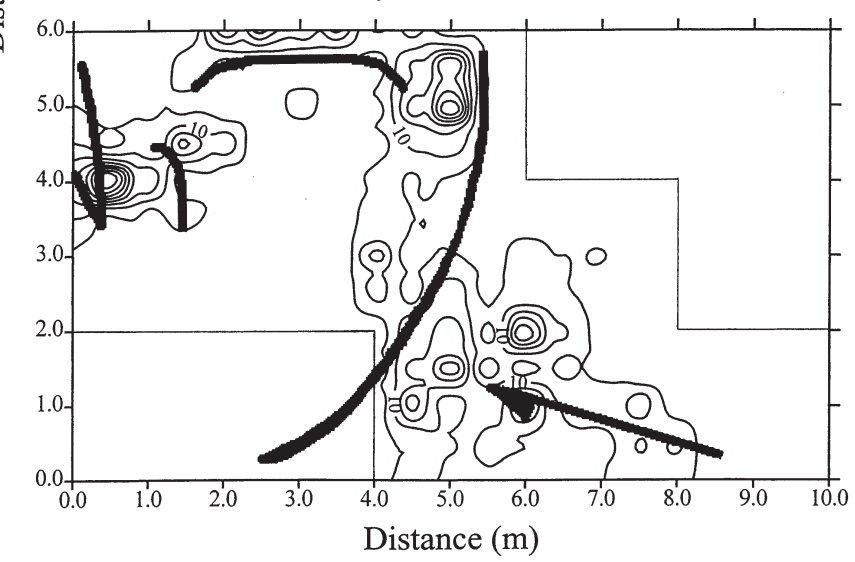

Fig. 1. (a) Contour map to illustrate variation in percentage cover of macroalgae (turf forming green algae) at the experimental site at Cape d'Aguilar, Hong Kong, in May 1995. Contours connect $10 \%$ isolines; (b) Contour map to illustrate variation in abundance of herbivorous molluscs (see Table 1 for species list) at the experimental site, Cape d'Aguilar, Hong Kong, in May 1995. Contours connect 10 molluscan herbivores $0.25 \mathrm{~m}^{-2}$ isolines. For both panels, the location of crevices (impressions in the rock surface greater than $3 \mathrm{~cm}$ ) in the rock substratum are indicated by the thick lines geneity of variances, despite subsequent transformations. The outcome of this ANOVA should, therefore, be interpreted with caution, although as group sizes were equal, ANOVA is thought to be relatively robust to such heterogeneity (Underwood 1997).

\section{RESULTS}

\section{Initial assemblage structure}

Dense green algal turfs (e.g. Enteromorpha spp. and Ulva spp.) were found on relatively homogeneous bedrock (Fig. 1), whilst areas in close proximity to crevices and surface irregularities tended to have low algal cover, or a thin film of Hildenbrandia rubra. Numerous herbivorous molluscs were patchily distributed in these crevices and depressions (Fig. 1, Table 1). Lower on the shore, films of $H$. rubra and patches of Hapalospongidion gelatinosum and Ralfsia expansa were found as well as a number of other herbivores (e.g. Lunella coronata and Chlorostoma spp., see Williams 1993a, Kaehler \& Williams 1996). Overall there was a negative relationship between cover of green turfs and the abundance of herbivores (Slope $=-0.55$; ANOVA, $F_{1,158}=5.88, \mathrm{p}=0.016$ ).

\section{Macroalgal and biofilm abundance (visual cover)}

Succession from burnt rock surfaces was rapid in all treatments where biofilms quickly developed (after $8 \mathrm{~d}$, Fig. 2) especially in herbivore exclusions ( 80\% cover

Table 1. Mean densities $( \pm \mathrm{SD})$ of abundant species $(>0.1$ $0.25 \mathrm{~m}^{-2}$ ) and maximum densities of molluscan herbivores at the study site at Cape d'Aguilar, Hong Kong

\begin{tabular}{|lccc|}
\hline \multirow{2}{*}{ Species } & \multicolumn{3}{c|}{ Density $0.25 \mathrm{~m}^{-2}$} \\
& Mean & SD & Maximum \\
\hline Monodonta labio & 3.95 & 7.72 & 44 \\
Nerita albicilla & 0.90 & 2.2 & 18 \\
Cellana toreuma & 0.80 & 1.9 & 14 \\
Patelloida pygmea & 0.39 & 1.0 & 5 \\
Lunella coronata & 0.39 & 0.96 & 5 \\
Acanthopleura japonica & 0.32 & 1.4 & 11 \\
Chlorostoma spp. & 0.12 & 0.59 & 5 \\
Total herbivores & $\mathbf{7 . 1 4}$ & $\mathbf{1 0 . 1}$ & $\mathbf{5 4}$ \\
Also recorded (<0.1 0.25 $\mathrm{m}^{-2}$ ) & & & \\
Siphonaria japonica & & & 2 \\
Siphonaria atra/sirius & & & 2 \\
Patelloida saccharina & \multicolumn{4}{|}{} \\
Nodilittorina vidua & & & \\
Individuals recorded & & \\
Planaxis sulcatus; Monodonta neritoides; \\
Nipponoacmea sp.
\end{tabular}


as compared to $\sim 20$ to $40 \%$ in herbivore access treatments, Fig. 2; Table 2). There were consistent differences in the algal assemblage supported in treatments with and without herbivores, in areas with and without algae, and also in the interaction between these 2 factors. There were also interactions between herbivore and mucus treatments and at one time a 3-way interaction (Table 2). Herbivore exclusions showed a succession from biofilms to green turfs (principally Enteromorpha spp., Fig. 2) which dominated ( 80\% cover) these treatments, in both locations, between Days 20 and 60. After $61 \mathrm{~d}$, however, the green turfs bleached white and died and were replaced by colonies of the encrusting brown alga Hapalospongidion gelatinosum, which dominated until the end of the experiment (Fig. 2).

Areas which allowed herbivores access, in general, did not develop such dense green turfs (Fig. 2), but maintained a persistent, visual biofilm for most of the experiment (Table 3). These films also burnt off and were replaced towards the end of the experiment by Hapalospongidion gelatinosum. Treatments in originally dense algal cover areas far from crevices (+A areas), supported a significantly higher cover of green turfs than treatments in originally sparse algal cover areas close to crevices where biofilms persisted (Fig. 2, Table 3).

The application of mucus alone had no impact on the development of the algal assemblage, but it had an interactive effect with herbivore treatments (Table 2). In the early stages of succession, in herbivore exclusions, green turfs were more abundant in areas which did not receive a mucus coating, whereas later in the succession biofilm cover was greater in areas which received a mucus coating (Table 3 ).

The interaction between algal areas and herbivore presence/absence revealed that where herbivores were excluded in areas with algae far from crevices, green turfs developed between 40 and $60 \mathrm{~d}$, but did not persist (Fig. 2, Table 3). At the peak of their dominance (May 26), green turfs had the greatest cover in herbivore exclusions in originally high algal cover areas, followed by herbivore exclusions in originally sparse algal cover areas close to crevices (Fig. 2, Table 3). In treatments which allowed herbivore access, green turfs were also more abundant in originally dense algal cover areas far from crevices as compared to areas which originally had a sparse cover and were close to crevices (Table 3), indicating an interaction of location and herbivore presence/absence. Biofilm abundance was negatively associated with green turfs, being highest in herbivore access treatments where algal abundance was initially low, i.e. close to crevices (Fig. 2, Table 3). Biofilm cover was very low in herbivore exclusions in either algal loca- tion, owing to the high abundance of green turfs. The 3 -way interaction (June 13) revealed that green turfs were more abundant in areas which originally supported algae, where a mucus coating was applied and where herbivores were allowed access (Table 3).

\section{MUCUS APPLICATION}
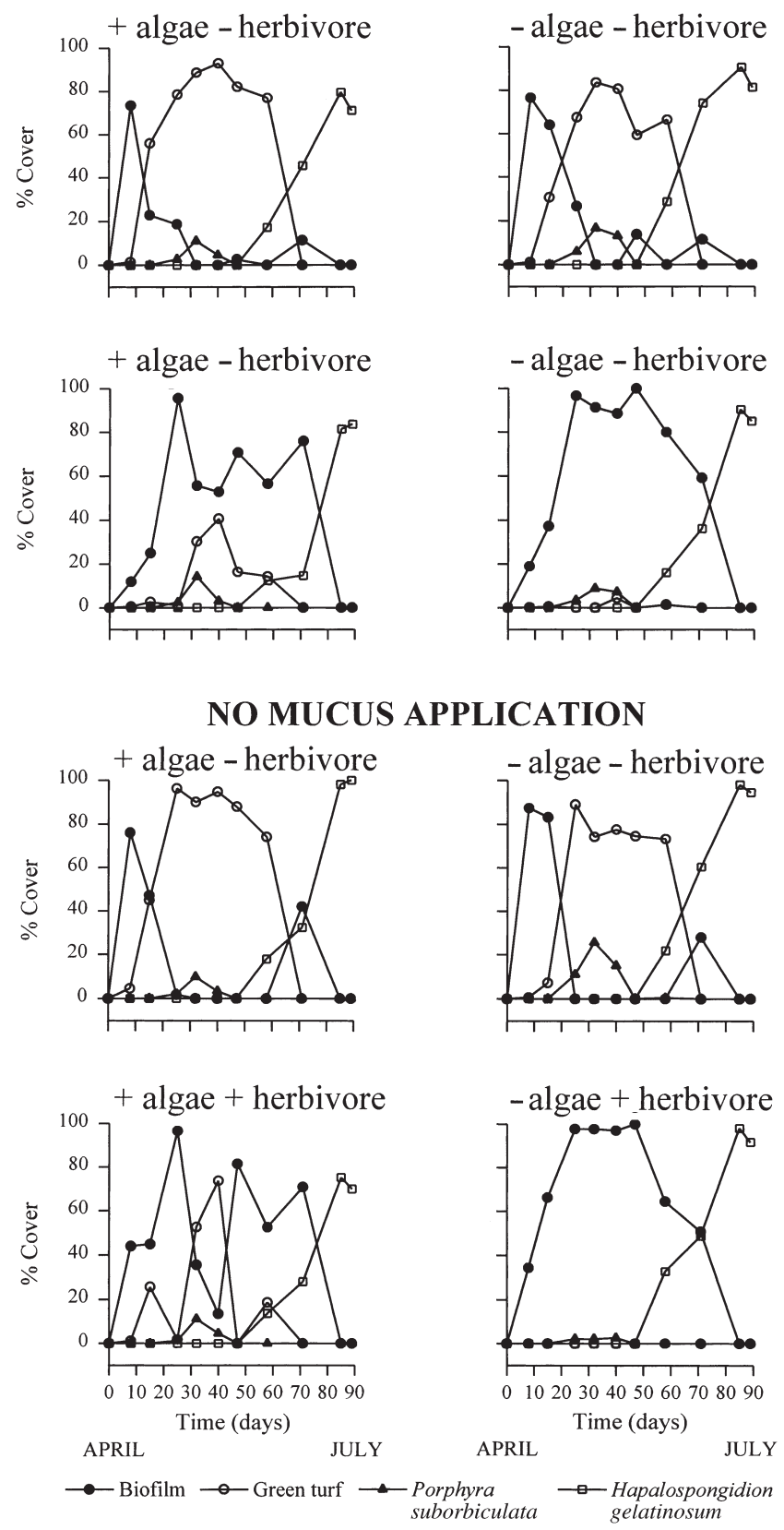

Fig. 2. Variation in mean percentage cover $(n=5)$ of visible macroalgae and biofilms in different experimental treatments with time $(+$ algae $=$ areas originally with dense algal cover; -algae $=$ areas with sparse algal cover $;$ +herbivores = partially fenced areas which allow herbivores access, -herbivores = fully fenced areas that excluded molluscan herbivores). Error bars have been omitted for clarity 
Table 2. Summary of 4 -way ANOVAs to investigate variation in visual cover of algae $(\mathrm{F}=$ biofilms; $\mathrm{G}=$ green turfs; $P=P$ Porphyra suborbiculata; $H=$ Hapalospongidion gelatinosum) with time in experimental treatments (for denominators of $F$-ratios see Table 7). Data were arc-sine transformed prior to analysis. $\mathrm{N}=$ not significant, ${ }^{*} \mathrm{p}<0.05$

\begin{tabular}{|c|c|c|c|c|c|c|c|c|c|c|c|}
\hline \multirow[t]{2}{*}{ Algal groups } & \multicolumn{11}{|c|}{ Sampling date } \\
\hline & $\mathrm{df}$ & $\begin{array}{c}\text { Apr } 24 \\
\text { F }\end{array}$ & $\begin{array}{c}\text { May } 1 \\
\text { F G }\end{array}$ & $\begin{array}{c}\text { May } 11 \\
\text { F G } P\end{array}$ & $\begin{array}{c}\text { May } 18 \\
\text { F G } P\end{array}$ & $\begin{array}{c}\text { May } 26 \\
\text { F G } P\end{array}$ & $\begin{array}{c}\text { Jun } 2 \\
\text { F G }\end{array}$ & $\begin{array}{c}\text { Jun } 13 \\
\text { F G } H\end{array}$ & $\begin{array}{c}\text { Jun } 26 \\
\text { F } H\end{array}$ & $\begin{array}{c}\text { Jul } 10 \\
H\end{array}$ & $\begin{array}{c}\text { Jul } 14 \\
H\end{array}$ \\
\hline Algae (A) & 1 & $\mathrm{~N}$ & ${ }^{*} \mathrm{~N}$ & N N N & ${ }^{*} * \mathrm{~N}$ & ${ }^{*} * \mathrm{~N}$ & $\mathrm{~N} \mathrm{~N}$ & N N N & $\mathrm{N}^{*}$ & $\mathrm{~N}$ & $\mathrm{~N}$ \\
\hline Mucus (M) & 1 & $\mathrm{~N}$ & $\mathrm{NN}$ & N N N & N N N & N N N & $\mathrm{N} \mathrm{N}$ & N N N & $\mathrm{N} \mathrm{N}$ & $\mathrm{N}$ & $\mathrm{N}$ \\
\hline Herbivores $(\mathrm{H})$ & 1 & * & $\mathrm{N}^{*}$ & $* * *$ & $*^{*} * *$ & ${ }^{*} * \mathrm{~N}$ & ** & ${ }^{*} * \mathrm{~N}$ & ${ }^{*} \mathrm{~N}$ & $\mathrm{~N}$ & $\mathrm{~N}$ \\
\hline $\mathrm{A} \times \mathrm{M}$ & 1 & $\mathrm{~N}$ & $\mathrm{~N} \mathrm{~N}$ & N N N & N N N & N N N & $\mathrm{N} \mathrm{N}$ & N N N & $\mathrm{N} \mathrm{N}$ & $\mathrm{N}$ & $\mathrm{N}$ \\
\hline $\mathrm{A} \times \mathrm{H}$ & 1 & $\mathrm{~N}$ & $\mathrm{~N} \mathrm{~N}$ & N N N & ${ }^{*} \mathrm{~N}^{*}$ & ${ }^{*} * \mathrm{~N}$ & $\mathrm{~N} \mathrm{~N}$ & N N N & $\mathrm{N} \mathrm{N}$ & $\mathrm{N}$ & $\mathrm{N}$ \\
\hline $\mathrm{M} \times \mathrm{H}$ & 1 & $\mathrm{~N}$ & $\mathrm{~N}^{*}$ & N N N & N N N & N N N & $\mathrm{N} \mathrm{N}$ & N N N & ${ }^{*} \mathrm{~N}$ & $\mathrm{~N}$ & * \\
\hline $\mathrm{A} \times \mathrm{M} \times \mathrm{H}$ & 1 & $\mathrm{~N}$ & $\mathrm{NN}$ & N N N & N N N & N N N & $\mathrm{N} \mathrm{N}$ & $\mathrm{N}^{*} \mathrm{~N}$ & $\mathrm{~N} \mathrm{~N}$ & $\mathrm{~N}$ & $\mathrm{~N}$ \\
\hline Areas (Algae, A) & 8 & No test & & & & & & & & & \\
\hline Areas $(\mathrm{A}) \times \mathrm{M}$ & 8 & No test & & & & & & & & & \\
\hline Areas $(\mathrm{A}) \times \mathrm{H}$ & 8 & No test & & & & & & & & & \\
\hline Areas $(\mathrm{A}) \times \mathrm{M} \times \mathrm{H}$ & 8 & No test & & & & & & & & & \\
\hline Total & 39 & & & & & & & & & & \\
\hline
\end{tabular}

Table 3. Student-Neumann-Keuls tests for significant factors from ANOVAs to investigate variation in visual cover of macroalgae at various sample dates $(+\mathrm{A}=$ areas originally with dense algal cover, $-\mathrm{A}=$ areas originally with sparse algal cover, $+\mathrm{H}=$ partial fence, herbivore access, $-\mathrm{H}=$ complete fence, herbivore exclusion). Where factors were involved in higher-order interactions, these have not been tested (NT)

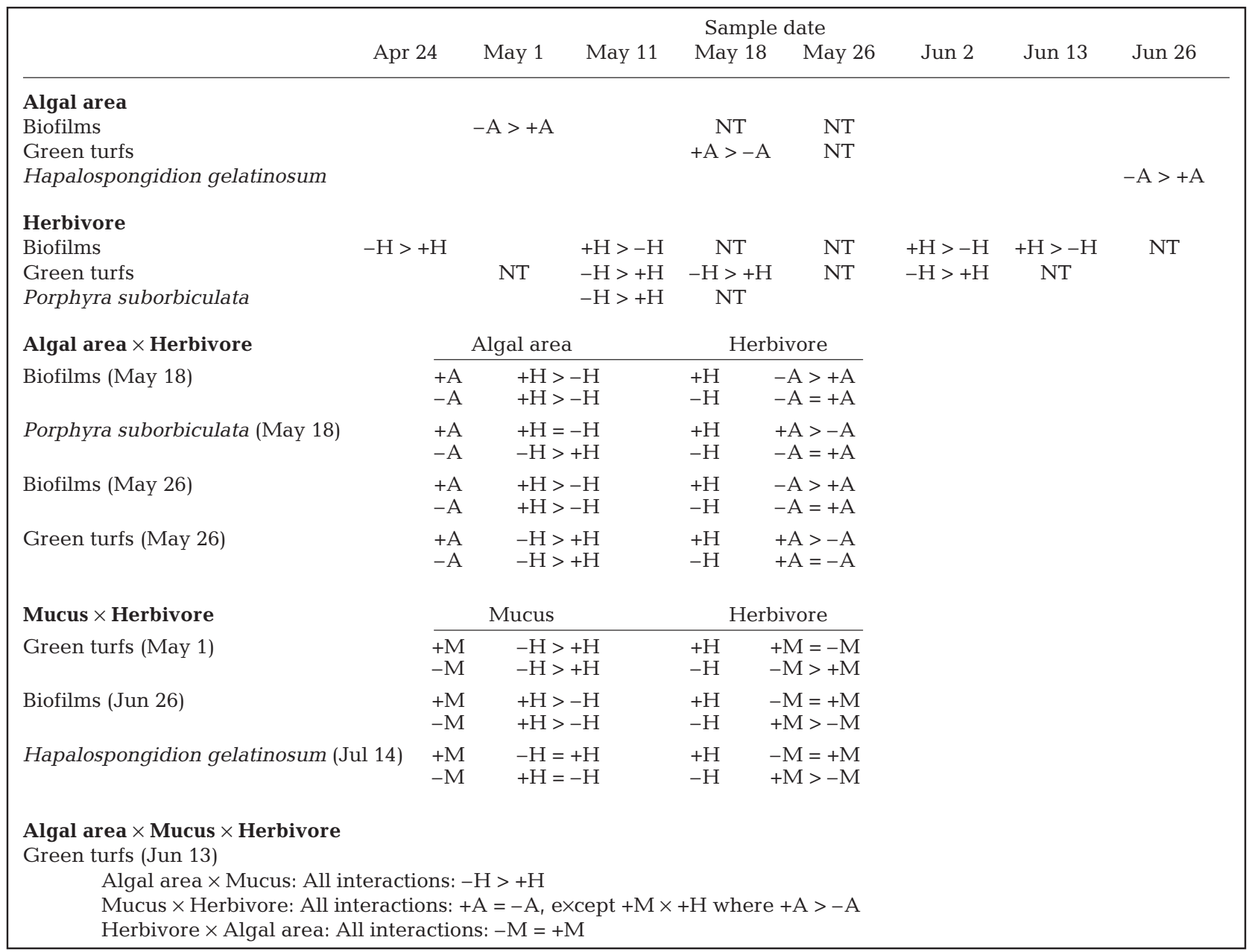


The foliose red alga Porphyra suborbiculata appeared briefly between 20 and $40 \mathrm{~d}$ and was most abundant in herbivore exclusions in originally sparse algal cover areas and herbivore access treatments in areas which originally had a dense algal cover close to crevices (Fig. 3, Table 3). After $71 \mathrm{~d}$, the encrusting brown alga Hapalospongidion gelatinosum settled and was more abundant in areas that had supported a sparse algal cover close to crevices and at the end of the experiment was more abundant in herbivore exclusions which had received a mucus coating although all treatments were dominated by a cover $>65 \%$ of $H$. gelatinosum (Figs. $2 \& 3$, Table 3).

\section{Microalgal and biofilm abundance (SEM)}

A total of 13 cyanobacterial species, a variety of diatoms (e.g. Melosira sp., Achnanthes spp. and Cocconeis spp.), sporelings of macroalgae (Porphyra suborbiculata and Enteromorpha spp.) and crusts of Hapalospongidion gelatinosum could be identified under the SEM. Cyanobacteria species could be separated into 3 major groups (Table 4). Within these groups Aphanocapsa sesciacensis and Dermocarpa sp. were most abundant in the unicellular group and Borzia sp. within the non-heterocystous filamentous group. Calothrix spp. and Lyngbya semiplena were, in general, rare $(<5 \%$ cover $)$. There was a general pattern of succession from diatoms to macroalgal sporelings and unicellular cyanobacteria, then Phormidium (including Borzia sp.), and finally the encrusting brown alga $H$. gelatinosum together with unicellular cyanobacteria (Figs. $3 \& 4$ ).

Overall, the principal impact on species observed under the SEM was the exclusion of herbivores (Table 5), although the presence of mucus and 2-way interactions between algal area, mucus and herbivore exclusion were sometimes important and at one time (June 2) there was a significant 3-way interaction (Table 5). Initial colonization occurred within $8 \mathrm{~d}$ by diatoms, which were more abundant $(\sim 30 \%)$ in herbivore exclusions, and after $\sim 3 \mathrm{wk}$, in areas which had received a mucus coating (Fig. 3, Table 6).

Porphyra suborbiculata and Enteromorpha spp. recruited after $2 \mathrm{wk}$ and sporelings of these algae were dominant in all herbivore exclusions ( $>60 \%$, Fig. 3, Tables $5 \& 6$ ). After $\sim 1 \mathrm{mo}$, macroalgae were more abundant in herbivore exclusions, especially in areas which originally had a dense algal cover far from crevices, and in herbivore access treatments in areas which originally had a sparse algal cover, close to crevices (Table 6). By June 13, macroalgae were still more abundant in herbivore exclusions, irrespective of their location. In herbivore access treatments that had received a mucus ap- plication, however, macroalgae were more abundant as compared to areas which had not received an additional mucus coating (Fig. 3, Table 6).

Unicellular cyanobacteria and Phormidium species (Table 4) were more abundant in areas which allowed

\section{MUCUS APPLICATION}
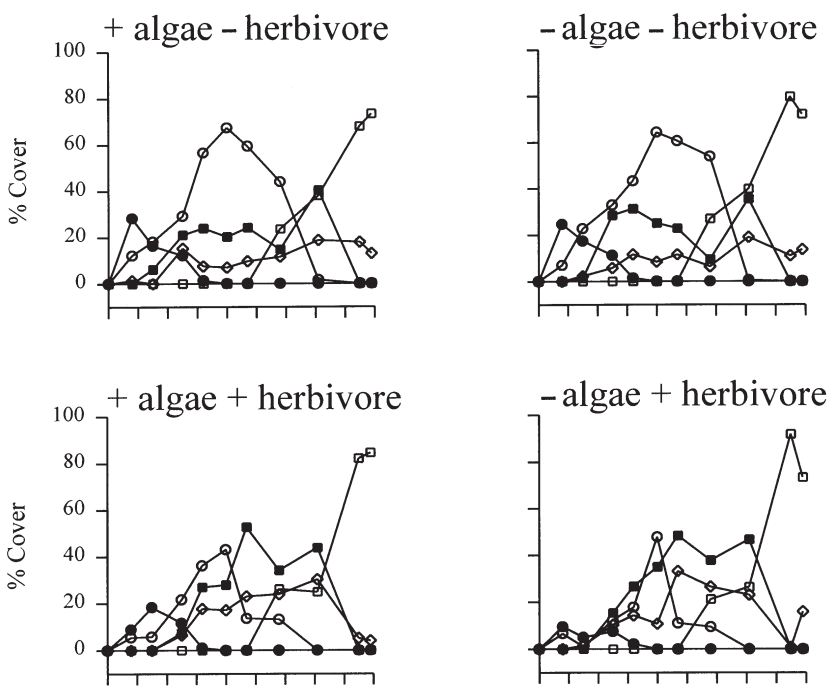

\section{NO MUCUS APPLICATION}
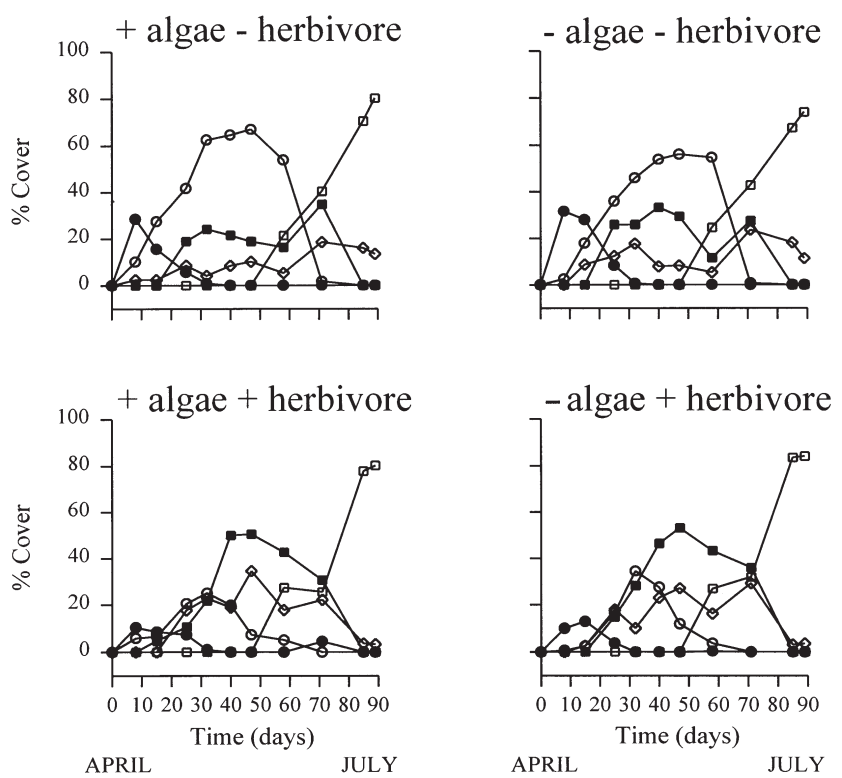

- Macroalgae - -Diatoms $\rightarrow$ Unicellular

- Phormidium spp. $\rightarrow$ Hapalospongidion gelatinosum

Fig. 3. Variation in mean percentage cover $(n=5)$ of various species/groups scored from rock chips under the SEM in different experimental treatments with time $(+$ algae $=$ areas originally with dense algal cover $;$-algae $=$ areas with sparse algal cover $;$ +herbivores = partially fenced areas which allow herbivores access, - herbivores = fully fenced areas that exclude molluscan herbivores). Error bars have been omitted for clarity 
herbivores access, suggesting a negative association between abundance of macroalgae and these cyanobacteria and, at one time (May 26) for Phormidium species, treatments which had not received an extra mucus application (Table 6). After 32 d (May 18), the abundance of unicellular cyanobacteria interacted with algal area and herbivore exclusion, being higher in areas which originally had a dense algal cover far from crevices and which allowed herbivores access.
Foliose macroalgae started to decrease after $~ 60 \mathrm{~d}$ in all treatments to be replaced by Hapalospongidion gelatinosum (Fig. 3), which initially was more abundant in herbivore exclusions, but later in herbivore access treatments and treatments that had received a mucus coating (Table 6). As the macroalgae died back the 3-way interaction (June 2, Table 6) revealed that the highest abundance was maintained in areas which allowed herbivore access, in areas that originally supported a dense algal cover far from crevices and re-
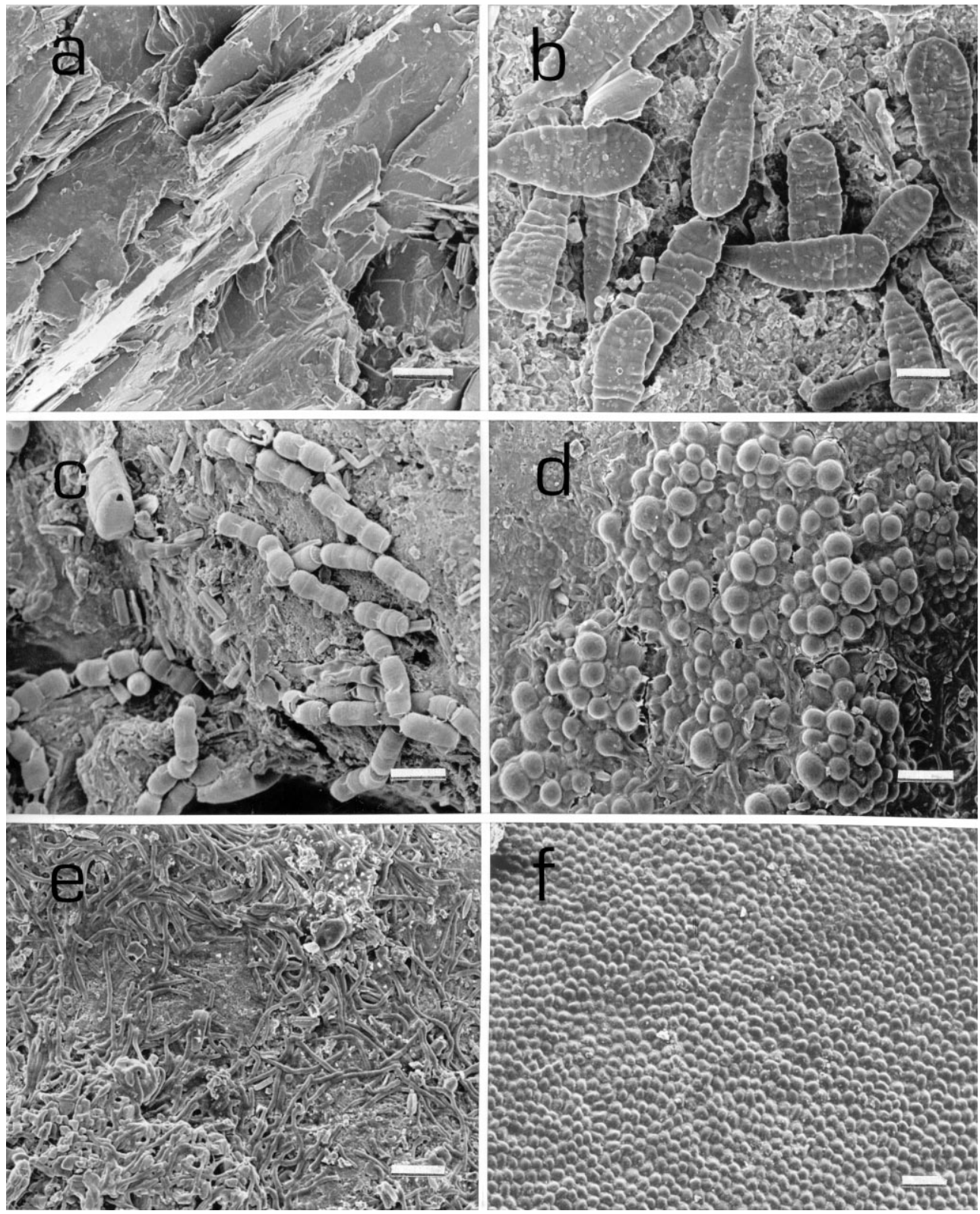

Fig. 4. Selected SEM photographs of the biofilm during primary succession. (a) Newly created, bare rock surface just after burning with a blowtorch; (b) sporelings of Porphyra suborbiculata; (c) initial colonization of diatoms (Melosira sp.); (d) colonies of unicellular cyanobacterium Aphanocapsa sesciacensis; (e) filaments of Phormidium spp.; (f) surface layer of the encrusting alga Hapalospongidion gelatinosum. Scale bars $=20 \mu \mathrm{m}$ 
ceived a mucus coating. Associated with the dieback of the macroalgae, Phormidium species were more abundant in treatments which received additional mucus in late June (Table 6). All species, however, had died back by the end of the experimental period, except for unicellular cyanobacteria spp., which were more abundant in herbivore exclusions, and $H$. gelatinosum which dominated all treatments.

\section{Microalgal and biofilm biomass (chl a levels)}

Chlorophyll $a$ levels increased in the early stages of the experiment and peaked after $32 \mathrm{~d}$ (May 18, Fig. 5), after which levels decreased to stabilise at $\sim 2 \mu \mathrm{g} \mathrm{cm}^{-2}$ after $85 \mathrm{~d}$ (July 10), similar to the first $2 \mathrm{wk}$ of the experiment. At the time of peak abundance, chl a levels were significantly higher in herbivore exclusions (Table 7) and in herbivore access treatments in the high algal cover areas far from crevices (Fig. 5, Table 7), indicating an interaction between location and herbivore impact. The lowest chl a levels were recorded in the originally sparse algal cover areas close to crevices which allowed herbivore access (Fig. 5, Table 7). The application of mucus had no impact on chl a levels. The effects of herbivore exclusion appeared to vary with time (Fig. 5). There was little apparent difference between herbivore access and exclusion treatments at the start of the experiment (up to $2 \mathrm{wk}$ ) or at the end of the experiment (the last $30 \mathrm{~d}$, June 26 to July 25) and it was only in the middle stages of the experiment, that chl a levels were generally high, when exclusions had higher chl $a$ levels than treatments which allowed herbivore access (Table 7).
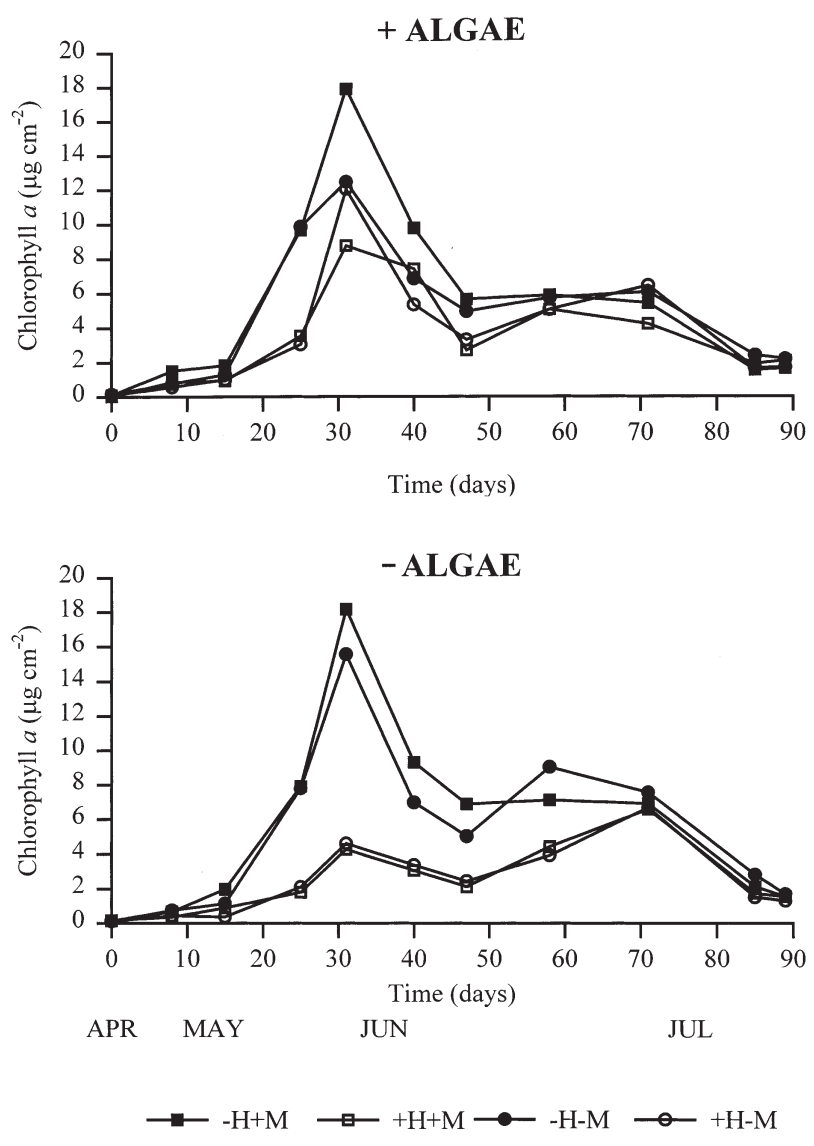

Fig. 5. Variation in mean chl a concentration $(n=5)$ in different experimental treatments with time. $+\mathrm{H}=$ partially fenced areas which allow herbivores access, $-\mathrm{H}=$ fully fenced areas that exclude molluscan herbivores, $+\mathrm{M}=$ mucus treatments, $-\mathrm{M}=$ no mucus applied. Error bars have been omitted for clarity

Table 4. Qualitative changes in cyanobacteria species abundance in experimental treatments with time. A $=$ most abundant species in group; $\mathrm{C}=$ common in group but $<25 \%$ as compared to the most abundant species; $\mathrm{R}=$ rare $(<1 \%$ cover $)$

Sample date

Apr 24 May 1 May 11 May 18 May 26 Jun 2 Jun 13 Jun 26 Jul $10 \quad$ Jul 14

Unicellular group

Aphanocapsa sesciacensis

Dermocarpa sp.

Gloeocapsa crepidinum

Chroococcus minor

Non-heterocystous-filamentous group

Borzia sp.

Phormidium tenue

Phormidium corium

Symploca laete-viridis

Spirulina labyrinthiformis

Lyngbya semiplena

Calothrix group

Calothrix contarenii

Calothrix crustacea

Calothrix scopulorum

$\begin{array}{llllllllll}\mathrm{A} & \mathrm{A} & \mathrm{A} & \mathrm{A} & \mathrm{A} & \mathrm{A} & \mathrm{A} & \mathrm{A} & \mathrm{A} & \mathrm{A} \\ \mathrm{A} & \mathrm{A} & \mathrm{A} & \mathrm{A} & \mathrm{A} & \mathrm{A} & \mathrm{A} & \mathrm{A} & \mathrm{A} & \mathrm{A} \\ \mathrm{C} & \mathrm{C} & \mathrm{C} & \mathrm{C} & & & & & & \\ \mathrm{C} & \mathrm{C} & \mathrm{C} & \mathrm{C} & \mathrm{C} & & & & & \\ & & & & & & & & \\ & \mathrm{A} & \mathrm{A} & \mathrm{A} & \mathrm{A} & \mathrm{A} & \mathrm{A} & \mathrm{A} & \\ \mathrm{C} & \mathrm{C} & \mathrm{C} & \mathrm{C} & & & & \\ & \mathrm{C} & \mathrm{C} & \mathrm{C} & \mathrm{C} & \mathrm{C} & \mathrm{C} & & \\ & \mathrm{R} & \mathrm{R} & \mathrm{R} & \mathrm{R} & \mathrm{R} & \mathrm{R} & \\ \mathrm{R} & \mathrm{R} & \mathrm{R} & \mathrm{R} & \mathrm{R} & \mathrm{R} & \mathrm{R} & & \\ \mathrm{R} & \mathrm{R} & & & & & & & \mathrm{R} \\ & & & & & & & \mathrm{R}\end{array}$


Table 5. Summary of 4-way ANOVAs to investigate variation in cover of algae and biofilm species/groups scored under the SEM (MA = macroalgae; Porphyra suborbiculata and Enteromorpha spp.; D = diatoms; U = unicellular cyanobacteria $P M=P h o r m i d-$ ium spp.; $H=$ Hapalospongidion gelatinosum) with time in experimental treatments (for denominators of $F$-ratios see Table 7 ).

Percentage data were arc-sine transformed prior to analysis. $\mathrm{N}=$ not significant, ${ }^{*} \mathrm{p}<0.05$

\begin{tabular}{|c|c|c|c|c|c|c|c|c|c|c|c|}
\hline Algal groups & $\mathrm{df}$ & $\begin{array}{l}\text { Apr } 24 \\
\text { MA D }\end{array}$ & $\begin{array}{l}\text { May } 1 \\
\text { MA D }\end{array}$ & $\begin{array}{c}\text { May } 11 \\
\text { MA D U PM }\end{array}$ & $\begin{array}{c}\text { Say } 18 \\
\text { MA U } P M\end{array}$ & $\begin{array}{l}\text { ampling dat } \\
\text { May } 26 \\
\text { MA U PM }\end{array}$ & $\begin{array}{l}\text { Jun } 2 \\
\text { MA U PM }\end{array}$ & $\begin{array}{c}\text { Jun } 13 \\
\text { MA U PMH }\end{array}$ & $\begin{array}{l}\text { Jun } 26 \\
\text { U } P H\end{array}$ & $\begin{array}{c}\text { Jul } 10 \\
\text { U } H\end{array}$ & $\begin{array}{c}\text { Jul } 14 \\
\text { U } H\end{array}$ \\
\hline Algae (A) & 1 & $\mathrm{~N} \mathrm{~N}$ & $\mathrm{~N} \mathrm{~N}$ & $\mathrm{~N} N \mathrm{~N}$ & $\mathrm{~N} N \mathrm{~N}$ & $\mathrm{~N} N \mathrm{~N}$ & $\mathrm{~N} N \mathrm{~N}$ & $\mathrm{~N} N \mathrm{~N}$ & $\mathrm{~N} N \mathrm{~N}$ & $\mathrm{~N} \mathrm{~N}$ & $\mathrm{~N} \mathrm{~N}$ \\
\hline Mucus (M) & 1 & $\mathrm{~N} \mathrm{~N}$ & $\mathrm{~N} \mathrm{~N}$ & $\mathrm{~N} * \mathrm{~N} \mathrm{~N}$ & $\mathrm{~N} N \mathrm{~N}$ & ${ }^{*} \mathrm{~N} *$ & $\mathrm{~N} N \mathrm{~N}$ & $\mathrm{~N} * \mathrm{~N} \mathrm{~N}$ & $\mathrm{~N} * \mathrm{~N}$ & $\mathrm{~N}^{*}$ & $\mathrm{~N} \mathrm{~N}$ \\
\hline Herbivores $(\mathrm{H})$ & 1 & $\mathrm{~N} *$ & ${ }^{*} \mathrm{~N}$ & ${ }^{*} \mathrm{~N} \mathrm{~N}{ }^{*}$ & ${ }^{*} \mathrm{~N} \mathrm{~N}$ & ${ }^{*} *^{*} *$ & $*{ }^{*} \quad *$ & ${ }^{*} *^{*}{ }^{*} \mathrm{~N}$ & $\mathrm{~N} \mathrm{~N}{ }^{*}$ & ${ }^{*} \quad *$ & ${ }^{*} \mathrm{~N}$ \\
\hline $\mathrm{A} \times \mathrm{M}$ & 1 & $\mathrm{~N} \mathrm{~N}$ & $\mathrm{~N} \mathrm{~N}$ & $\mathrm{~N} N \mathrm{~N} \mathrm{~N}$ & $\mathrm{~N} N \mathrm{~N}$ & $\mathrm{~N} \mathrm{~N} \mathrm{~N}$ & $\mathrm{~N} N \mathrm{~N}$ & $\mathrm{~N} N \mathrm{~N}$ & $\mathrm{~N} \mathrm{~N} \mathrm{~N}$ & $\mathrm{~N} \mathrm{~N}$ & $\mathrm{~N} \mathrm{~N}$ \\
\hline $\mathrm{A} \times \mathrm{H}$ & 1 & $\mathrm{~N} \mathrm{~N}$ & $\mathrm{~N} \mathrm{~N}$ & $\mathrm{~N} N \mathrm{~N} \mathrm{~N}$ & $\mathrm{~N}{ }^{*} \mathrm{~N}$ & ${ }^{*} \mathrm{~N} \mathrm{~N}$ & $\mathrm{~N} N \mathrm{~N}$ & ${ }^{*} \mathrm{~N} \mathrm{~N} \mathrm{~N}$ & $\mathrm{~N} \mathrm{~N} \mathrm{~N}$ & $\mathrm{~N} \mathrm{~N}$ & $\mathrm{~N} \mathrm{~N}$ \\
\hline $\mathrm{M} \times \mathrm{H}$ & 1 & $\mathrm{~N} \mathrm{~N}$ & $\mathrm{~N} \mathrm{~N}$ & $\mathrm{~N} N \mathrm{~N} \mathrm{~N}$ & $\mathrm{~N} \mathrm{~N} \mathrm{~N}$ & $\mathrm{~N} \mathrm{~N} \mathrm{~N}$ & $\mathrm{~N} N \mathrm{~N}$ & ${ }^{*} \mathrm{~N} \mathrm{~N} \mathrm{~N}$ & $\mathrm{~N} \mathrm{~N} \mathrm{~N}$ & $\mathrm{~N} \mathrm{~N}$ & $\mathrm{~N} \mathrm{~N}$ \\
\hline $\mathrm{A} \times \mathrm{M} \times \mathrm{H}$ & 1 & $\mathrm{~N} \mathrm{~N}$ & $\mathrm{~N} \mathrm{~N}$ & $\mathrm{~N} N \mathrm{~N} \mathrm{~N}$ & $\mathrm{~N} \mathrm{~N} \mathrm{~N}$ & $\mathrm{~N} \mathrm{~N} \mathrm{~N}$ & ${ }^{*} \mathrm{~N} \mathrm{~N}$ & $\mathrm{~N} N \mathrm{~N} \mathrm{~N}$ & $\mathrm{~N} \mathrm{~N} \mathrm{~N}$ & $\mathrm{~N} \mathrm{~N}$ & $\mathrm{~N} \mathrm{~N}$ \\
\hline Areas (Algae, A) & 8 & No test & & & & & & & & & \\
\hline Areas $(\mathrm{A}) \times \mathrm{M}$ & 8 & No test & & & & & & & & & \\
\hline Areas $(\mathrm{A}) \times \mathrm{H}$ & 8 & No test & & & & & & & & & \\
\hline Areas $(\mathrm{A}) \times \mathrm{M} \times \mathrm{H}$ & 8 & No test & & & & & & & & & \\
\hline Total & 39 & & & & & & & & & & \\
\hline
\end{tabular}

Table 6. Student-Neumann-Keuls tests for significant factors from univariate 4-way ANOVAs to investigate variation in cover of algae and biofilm species/groups scored under the SEM at various sample dates (for abbreviations see Table 3). Where factors were involved in higher-order interactions, these have not been tested (NT)

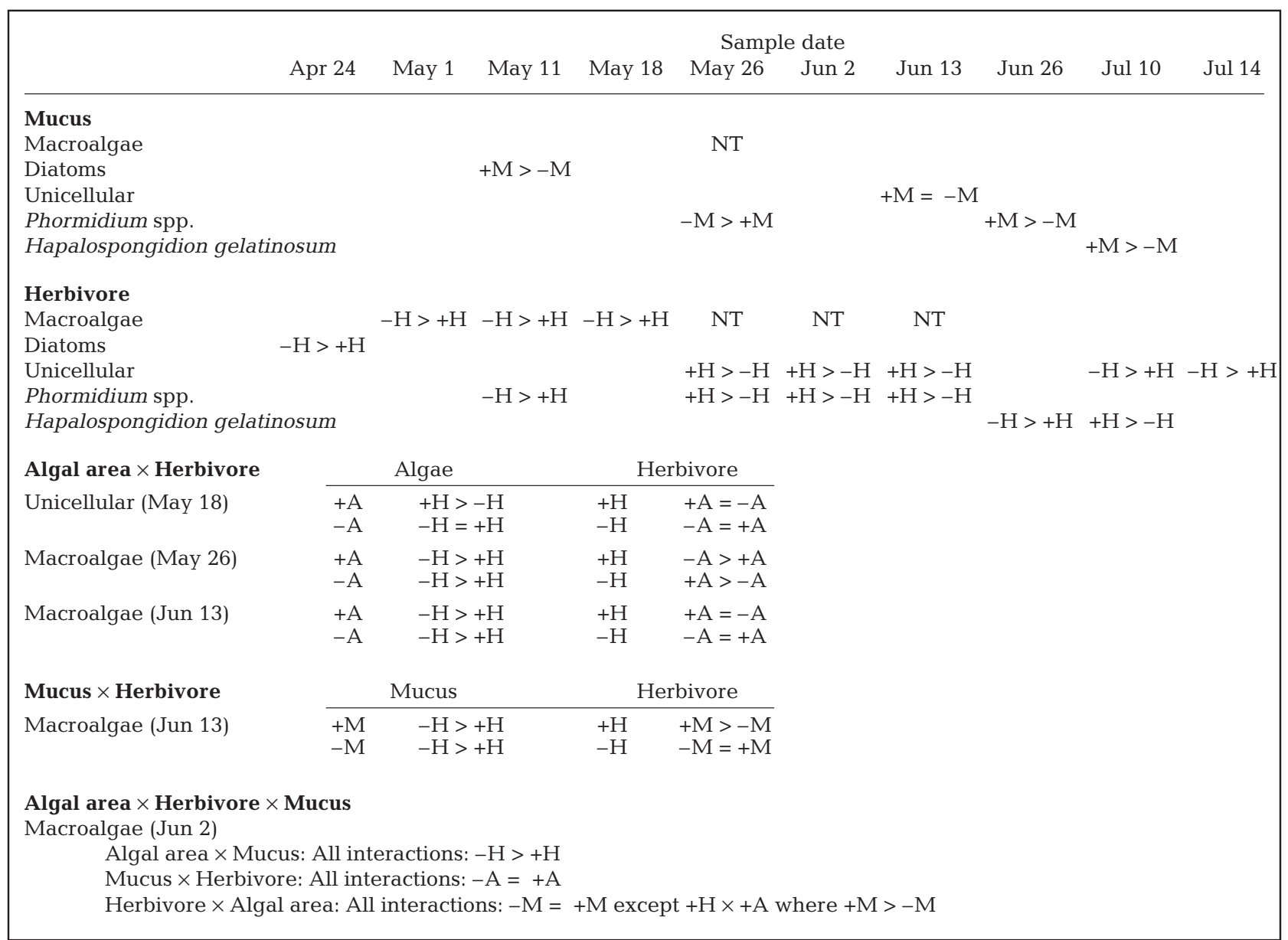




\section{DISCUSSION}

\section{Spatial patterns of species distributions}

In contrast to aseasonal tropical shores, where distribution patterns are temporally stable (e.g. the Bay of Panama, Lubchenco et al. 1984), Hong Kong shores of moderate exposure often support patches of ephemeral macroalgae in winter (Hodgkiss 1984, Williams 1993b, Kaehler \& Williams 1996). The causes of these temporal and spatial patterns have been suggested to be physical stresses in the summer, limiting ephemeral algae to the more benign winter (Hodgkiss 1984) or where physical stress is reduced (Kaehler \& Williams 1996). Grazing pressure may also limit algae to areas of the shore where herbivores are reduced in density or effectiveness, or to times when herbivory is reduced and/or algal productivity exceeds herbivore cropping (Williams 1993b, Kaehler \& Williams 1996).

Small-scale (i.e. $50 \times 50 \mathrm{~cm}$ areas) patterns at Cape d'Aguilar, Hong Kong, showed that the distribution of Ulva spp. and Enteromorpha spp. in winter was associated with open areas of substrate away from cracks and crevices in the rock. These irregularities in the rock provided a shelter for a variety of herbivorous molluscs (16 species) and areas close to these refuges were generally devoid of macroalgae. The resulting mosaic of bare rock areas and patches of algae on the shore is presumably mediated by the relative distance of these areas from herbivore refuges. A negative relationship between ephemeral macroalgae and herbivore abundance is common (Lein 1980), and where herbivores are limited spatially, this can cause a mosaic of patches on the shore (Vadas 1992). On tropical shores many mobile species are limited in their distribution to cracks and crevices, which provide a refuge against physical stresses (e.g. Nerita funiculata, Levings \& Garrity 1983) or predation (Menge et al. 1983, 1985). The actual cause of this pattern of algal distribution, therefore, appears to be substratum heterogeneity and its indirect impact of limiting the foraging range of herbivores (see Menge et al. 1985, Menge \& Olson 1990, Hixon \& Menge 1991).

Most herbivores in Hong Kong leave their crevices to feed on the flooding tide and retreat to suitable refuges on the ebbing tide (Hutchinson 1999, G.A.W. pers. obs.) a pattern which is common for tropical herbivores (Bertness et al. 1981, Garrity 1984, Williams \& Morritt 1995). The foraging distance which can be achieved is, therefore, a function of travel distance within a tidal period from a refuge (Levings \& Garrity 1983). Although other molluscan herbivores migrate into the intertidal zone with the flooding tide in Hong Kong, there is not the influx of highly mobile consumers (fish and crabs) recorded from other tropical shores (Menge \& Lubchenco 1981, Brosnan 1992, and see discussion in Sutherland \& Ortega 1986) which limits species to refuges from consumer pressure. The highly mobile

Table 7. Four-way ANOVA to investigate variation in chl a abundance on 18 May with the factors: the presence or absence of algae $(+\mathrm{A}=$ original dense algal area, $-\mathrm{A}=$ original sparse algal area), mucus $(+\mathrm{M}=$ mucus applied, $-\mathrm{M}=$ no mucus application) and herbivores $(+\mathrm{H}=$ partial fence, herbivore access,$-\mathrm{H}=$ full fence, herbivore exclusion) $(\mathrm{n}=5)$. It was not possible to transform data to meet assumptions of homogeneity of variances (see 'Materials and methods'). Significant differences indicated $\left({ }^{*}\right)$ and further examined by Student-Neumann-Keuls tests, although tests were not performed for factors involved in significant higherorder interactions

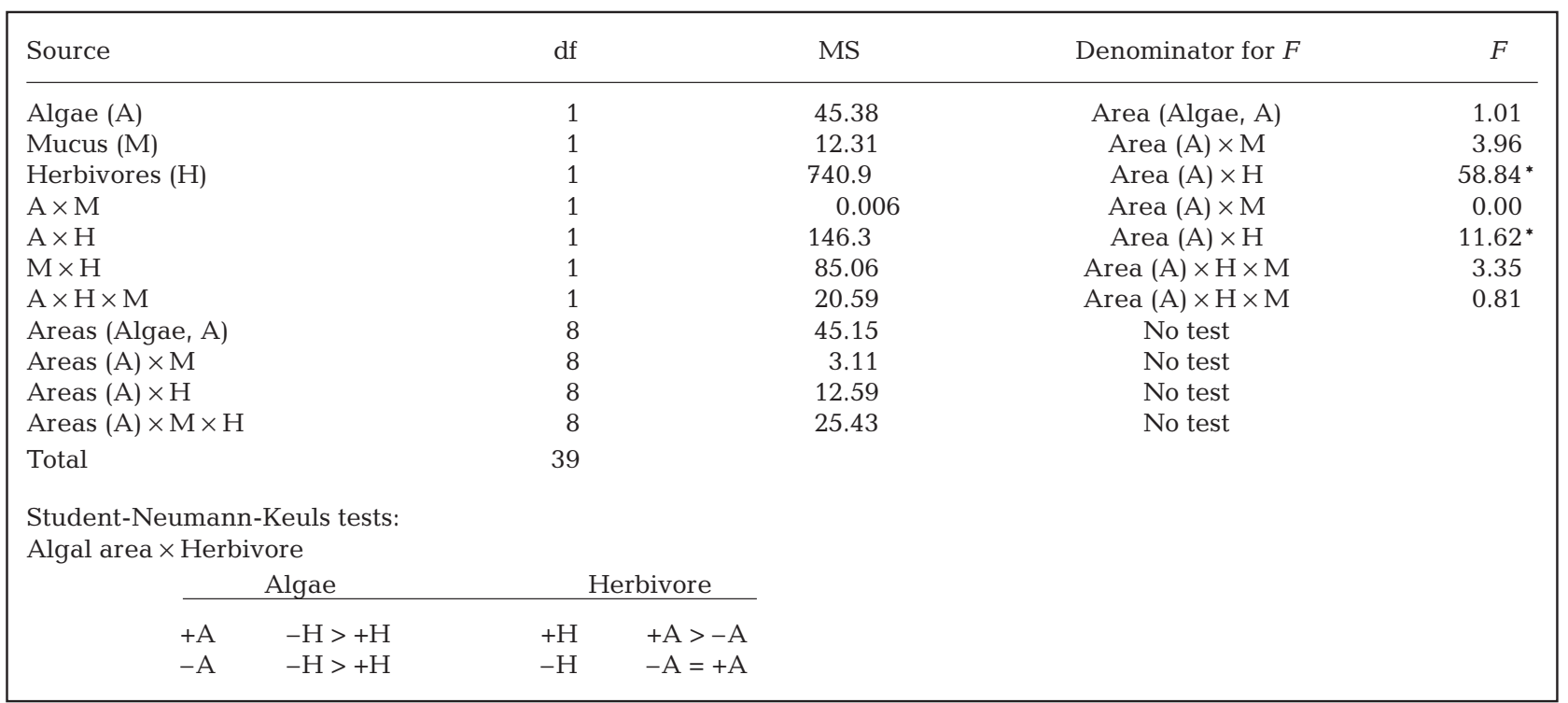


herbivorous crab Grapsus albolineatus is present at this site but was not abundant during the study period. As a result, ephemeral algae can achieve spatial escapes at distances from herbivore refuges, resulting in patches of algae within areas of high grazing pressure.

\section{Patterns of succession}

In herbivore exclusions, irrespective of location or whether mucus was added, there was a predictable pattern of colonization starting with a biofilm (diatoms and unicellular cyanobacteria) followed by a macroalgal phase (e.g. Enteromorpha spp. and Porphyra suborbiculata) after 20 to $30 \mathrm{~d}$. The rapid establishment of macroalgae is common following herbivore exclusion on temperate (reviewed by Sousa \& Connell 1992) and tropical shores during periods of reduced physical stress, or low on the shore (e.g. Lawson 1966, Sauer Machado et al. 1992, Williams 1993a,b, Kaehler \& Williams 1998).

In herbivore access treatments, succession was affected by treatment location. Herbivores maintained treatments close to crevices (the formerly sparse algal areas) in an arrested state of succession where a biofilm persisted. Herbivores, therefore, can prevent the development of ephemeral turfs when they have access to such areas. In treatments distant from herbivore refuges (the dense algal areas), green turfs did develop in herbivore access treatments. This indicates that either herbivores were unable to reach these areas to effectively crop the algae, or that these areas recruited more macroalgae as compared to areas near herbivore refuges (Benedetti-Cecchi \& Cinelli 1995). If the latter explanation was the case, then it would be expected that algal turf abundance in the herbivore exclusions in the 2 locations (i.e. near and far from crevices) should vary, but this did not occur. Herbivore effectiveness appears the most likely explanation, and this is in agreement with Levings \& Garrity (1983), who showed that Nerita funiculata maintained a $10 \mathrm{~cm}$ bare area around its refuges, and when removed, crustose algae grew in these areas. $N$. funiculata maintains small-scale (10 cm scale) patchiness on Panamanian shores, whereas the guild of molluscan herbivores in the present experiment were able to maintain bare areas $\sim 50 \mathrm{~cm}$ away from their refuges.

Mucus application had little effect, except on the biofilm when, in herbivore access treatments, macroalgal cover was almost twice as great in treatments which received a mucus coating as those which did not. This may represent a fertilizing impact of mucus on the early stages of ephemeral algal development. Mucus also had a limited impact, stimulating diatoms, unicellular cyanobacteria, Phormidium species, early settling stages of Hapalospongidion gelatinosum and visible biofilms following the dieback of green algae, especially in herbivore exclusion treatments. It was difficult to gauge the effectiveness of this treatment. The anticipated influence was in the initial stages of the experiment, mucus increasing microalgal settlement (Davies \& Hawkins 1998, Davies \& Beckwith 1999), but such impact was not clear (but may be present for settlement of diatoms), although the sampling interval ( $8 \mathrm{~d}$ ) may have been too long to detect this. The influence of mucus following the dieback of ephemeral algae may, however, represent such an impact. Mucus from limpets in Hong Kong has a shorter half-life (1 to 2 d) and traps less microalgae as compared to temperate species (Davies \& Williams 1995), suggesting that the possible role of mucus as a seeding layer in tropical areas is relatively less important than proposed for temperate shores.

There was a clearly negative relationship between cyanobacteria abundance and macroalgal cover. The competitive inhibition of other species by ephemeral algae is a well documented phenomenon (Sousa 1979). Such competition between species at low trophic levels has been proposed to take place only when predation pressure is reduced (see Brosnan 1992 for a review of the Menge \& Sutherland 1976, 1987 models), which would appear to be the case in the present situation; herbivore exclusion allows the development of ephemeral algae which dominate the rock surface and inhibit cyanobacterial films or other algae.

\section{Seasonal patterns}

There was a rapid change in algal assemblages with the onset of summer. Irrespective of herbivore access, area location or the application of mucus, macroalgae died back in all treatments after $\sim 60 \mathrm{~d}$ (mid-June) to be replaced by crusts of the brown alga Hapalospongidion gelatinosum. This alga can recruit during the winter, if space is available (Kaehler \& Williams 1997), but is competitively inferior to ephemeral species such as Enteromorpha spp. and Ulva spp. (Kaehler 1996). Once settled, however, recruits of $H$. gelatinosum are relatively resistant to physical stress (Kaehler \& Williams 1998). There was little consistent influence of any of the treatments on $H$. gelatinosum, the remaining epilithic biofilm or chl a levels at the end of the experiment, suggesting that the dominant structuring factor was physical stress.

The advent of the hot season on many seasonal tropical shores has a great impact on assemblages, causing high shore kills of both mobile and sessile species (e.g. Lawson 1966, Banaimoon 1988, Murthy et al. 1989; in 
Hong Kong, Williams 1994, Williams \& Morritt 1995, Kaehler \& Williams 1996, Nagarkar \& Williams 1999). The relative impact of herbivory is also seasonally variable in the Hong Kong mid-intertidal zone (Williams 1993b). In the present example, the competitive dominance of green algae is broken by physical stress, removing the stress-intolerant ephemeral algae and allowing more tolerant algae (the encrusting alga Hapalospongidion gelatinosum) to colonize. This is an annual event on seasonal tropical shores where rock space is liberated for colonization with the advent of the hot season, and this disturbance plays an important role in subsequent community structure (Williams 1993b, Kaehler \& Williams 1996).

On seasonal tropical shores, therefore, the dominant factors controlling assemblage structure vary with environmental conditions. In winter, assemblage structure in the mid-shore is controlled by grazing pressure, which is directly set by spatial refuges for molluscan herbivores. Processes appear similar to those described by Menge et al. (1986) on the low shore of the Bay of Panama, where consumer pressure controls species distribution patterns; only where species escape such pressure will competition be important. In Hong Kong, escapes from such pressure can be achieved spatially, if the rock surface available is far enough removed from refuges for the molluscan herbivores. In summer, however, physical conditions control assemblage structure, removing the fast-growing ephemeral algae and leaving only grazer-resistant and stress-tolerant species, the distribution of which is little affected by consumers in the mid-shore (see Sauer Machado et al. 1996). In tropical regions which experience strong monsoon conditions, the relative influences of physical and biological factors will vary seasonally. The relative roles of these factors are therefore likely to be variable between tropical regions (Sauer Machado et al. 1996) owing to climatic differences; hence even on a small-scale, generalizations concerning the importance of different processes should be made with caution.

Acknowledgements. Dr Sven Kaehler (Rhodes University, South Africa) and colleagues of the Hard Rock Ecology group, especially Neil Hutchinson (all The University of Hong Kong) commented on the manuscript. An anonymous reviewer and Dr Lisandro Benedetti-Cecchi (Pisa University, Italy) generously advised on statistical design and analysis. Dr Susan T. Hawkins kindly supplied caging material when we were in dire need! We are grateful to Ms Kelly, Lau Lai Yip, who helped with the fieldwork and prepared the figures; to Ms A. Wong and staff at the SEM Unit; and Dr P. C. Lai (Geography Department) for help with the contour maps (all at The University of Hong Kong). This research was supported by a Hong Kong University CRCG grant to G.A.W. and a Royal Society Travel Grant to M.S.D.

\section{LITERATURE CITED}

Banaimoon SA (1988) The marine algal flora of Khalf and adjacent regions, Hadramount, PDR Yemen. Bot Mar 31: 215-221

Benedetti-Cecchi L, Cinelli F (1995) Habitat heterogeneity, sea urchin grazing and the distribution of algae in littoral rock pools on the west coast of Italy (western Mediterranean). Mar Ecol Prog Ser 126:203-212

Bertness MD, Garrity SD, Levings SC (1981) Predation pressure and gastropod foraging: a tropical-temperate comparison. Evolution 35:995-1007

Brosnan DM (1992) Ecology of tropical rocky shores: plantanimal interactions in tropical and temperate latitudes. In: John DM, Hawkins SJ, Price JH (eds) Plant-animal interactions in the marine benthos, Special Vol 46. Systematics Association, Clarendon Press, Oxford, p 101-131

Carpenter RC (1986) Partitioning herbivory and its effects on coral reef algal communities. Ecol Monogr 56:345-363

Chapman MG, Underwood AJ (1992) Foraging behaviour of marine benthic grazers. In: John DM, Hawkins SJ, Price JH (eds) Plant-animal interactions in the marine benthos, Special Vol 46. Systematics Association, Clarendon Press, Oxford, p 289-317

Davies MS, Beckwith P (1999) The role of mucus trails and trail-following in the behaviour and nutrition of the periwinkle Littorina littorea. Mar Ecol Prog Ser 179:247-257

Davies MS, Hawkins SJ (1998) Mucus from marine molluscs. Adv Mar Biol 34:1-71

Davies MS, Williams GA (1995) Pedal mucus of a tropical limpet, Cellana grata (Gould): energetics, production and fate. J Exp Mar Biol Ecol 186:77-87

Garrity SD (1984) Some adaptations of gastropods to physical stress on a tropical rocky shore. Ecology 65:559-574

Hartnoll RG, Hawkins SJ (1985) Patchiness and fluctuations on moderately exposed rocky shores. Ophelia 24:53-63

Hawkins SJ, Hartnoll RG (1983) Grazing of intertidal algae by marine invertebrates. Oceanogr Mar Biol Annu Rev 21: 195-282

Hixon MA, Menge BA (1991) Species diversity: prey refuges modify the interactive effects of predation and competition. Theor Popul Biol 39:178-200

Hodgkiss IJ (1984) Seasonal patterns of intertidal algal distribution in Hong Kong. Asian Mar Biol 1:49-57

Hutchinson N (1999) Spatial variation on tropical rocky shores: the role of herbivory and disturbance. $\mathrm{PhD}$ thesis, The University of Hong Kong

John DM, Price JM, Lawson GW (1992) Tropical East Atlantic and islands: plant-animal interactions on shores free of biotic reefs. In: John DM, Hawkins SJ, Price JH (eds) Plantanimal interactions in the marine benthos, Special Vol 46. Systematics Association, Clarendon Press, Oxford, p 87-99

Kaehler S (1996) Causes and consequences of the spatial and temporal distribution of encrusting algae on tropical rocky shores. PhD thesis, The University of Hong Kong

Kaehler S, Williams GA (1996) Distribution of algae on tropical rocky shores: spatial and temporal patterns of noncoralline encrusting algae in Hong Kong. Mar Biol 125: $177-187$

Kaehler S, Williams GA (1997) Do factors influencing recruitment ultimately determine the distribution and abundance of encrusting algae on seasonal tropical shores? Mar Ecol Prog Ser 156:87-96

Kaehler S, Williams GA (1998) Early development of algal assemblages under different regimes of physical and biotic factors on a seasonal tropical rocky shore. Mar Ecol Prog Ser 172:61-71 
Lawson GW (1966) The littoral ecology of West Africa. Oceanogr Mar Biol Annu Rev 4:405-448

Lein TE (1980) The effects of Littorina littorea L. (Gastropoda) grazing on littoral green algae in the inner Oslofjord, Norway. Sarsia 65:87-92

Levings SC, Garrity SD (1983) Diel and tidal movement of two co-occurring neritid snails; differences in grazing patterns on a tropical rocky shore. J Exp Mar Biol Ecol 67:261-278

Lubchenco J, Menge BA, Garrity SD, Lubchenco PJ, Ashkensas LR, Gaines SD, Emlet R, Lucas J, Strauss S (1984) Structure, persistence, and role of consumers in a tropical rocky intertidal community (Taboguilla Island, Bay of Panama). J Exp Mar Biol Ecol 78:23-73

Menge BA, Lubchenco J (1981) Community organisation in temperate and tropical rocky intertidal habitats: prey refuges in relation to consumer pressure gradients. Ecol Monogr 51:429-450

Menge BA, Olson AM (1990) Role of scale and environmental factors in regulation of community structure. Trends Ecol Evol 5:52-57

Menge BA, Sutherland JP (1976) Species diversity gradients: synthesis of the roles of predation, competition, and temporal heterogeneity. Am Nat 110:351-367

Menge BA, Sutherland JP (1987) Community regulation: variation in disturbance, competition, and predation in relation to environmental stress and recruitment. Am Nat 130: $730-757$

Menge BA, Ashkensas LR, Matson A (1983) Use of artificial holes in studying community development in cryptic marine habitats in a tropical rocky intertidal region. Mar Biol 77:129-142

Menge BA, Lubchenco J, Ashkensas LR (1985) Diversity, heterogeneity and consumer pressure in a tropical rocky intertidal community. Oecologia 65:394-405

Menge BA, Lubchenco J, Ashkensas LR (1986) Experimental separation of effects of consumers on sessile prey in the low zone of a rocky shore in the Bay of Panama: direct and indirect consequences of food web complexity. J Exp Mar Biol Ecol 100:225-269

Morton BS, Williams GA, Lee SY (1996) The benthic marine ecology of Hong Kong: a dwindling heritage? In: Coastal infrastructure development in Hong Kong: a review Hong Kong Government, Hong Kong, p 233-267

Murthy MS, Ramakrishna T, Rao YN, Ghose DK (1989) Ecological studies on some agarophytes from Veraval Coast (India). I. Effects of aerial conditions on the biomass dynamics. Bot Mar 32:515-520

Nagarkar S (1998a) New records of marine cyanobacteria from rocky shores of Hong Kong. Bot Mar 41:527-542

Nagarkar S (1998b) New records of coccoid cyanobacteria from Hong Kong rocky shores. Asian Mar Biol 15:119-125

Nagarkar S, Williams GA (1997) Comparative techniques to quantify cyanobacteria dominated epilithic biofilms on tropical rocky shores. Mar Ecol Prog Ser 154:281-291

Nagarkar S, Williams GA (1999) Spatial and temporal variation of cyanobacteria-dominated epilithic communities on a tropical shore in Hong Kong. Phycologia 38:385-393

Nicotri ME (1977) Grazing effects of four marine intertidal herbivores on the microflora. Ecology 58:1020-1032

Editorial responsibility: John Austin (Assistant Editor), Oldendorf/Luhe, Germany
Santelices B, Ugarte R (1987) Algal life-history strategies and resistance to digestion. Mar Ecol Prog Ser 35:267-275

Sauer Machado KRS, Chapman ARO, Coutinho R (1992) Patch structure in a tropical rocky shore community in Brazil: a mosaic of successional states? Ophelia 35:187-195

Sauer Machado KRS, Chapman ARO, Coutinho R (1996) Consumer species have limited and variable roles in community organization on a tropical rocky shore. Mar Ecol Prog Ser 134:73-83

Sousa WP (1979) Experimental investigations of disturbance and ecological succession in a rocky intertidal algal community. Ecol Monogr 49:227-254

Sousa WP, Connell JH (1992) Grazing and succession in marine algae. In: John DM, Hawkins SJ, Price JH (eds) Plant-animal interactions in the marine benthos, Special Vol 46. Systematics Association, Clarendon Press, Oxford, p 425-441

Sutherland JP, Ortega S (1986) Competition conditional on recruitment and temporary escape from predators on a tropical rocky shore. J Exp Mar Biol Ecol 95:155-166

Underwood AJ (1985) Physical factors and biological interactions: the necessity and nature of ecological experiments. In: Moore PG, Seed R (eds) The ecology of rocky coasts. Hodder \& Stoughton, London, p 372-390

Underwood AJ (1997) Experiments in ecology. Cambridge University Press, Cambridge

Underwood AJ, Jernakoff P (1981) Effects of interactions between algae and grazing gastropods on the structure of a low-shore intertidal algal community. Oecologia 48: 221-223

Underwood AJ, Denley EJ, Moran MJ (1983) Experimental analyses of the structure and dynamics of mid-shore rocky intertidal communities in New South Wales. Oecologia 56: 202-219

Vadas RL (1985) Herbivory. In: Littler MM, Littler DS (eds) The handbook of phycological methods. Ecological field methods: macroalgae. Cambridge University Press, Cambridge, p 531-572

Vadas RL (1992) Littorinid grazing and algal patch dynamics. In: Mill PG, Reid DG, Grahame JW (eds) Proceedings of the Third International Symposium on Littorinid Biology. The Malacological Society of London, London, p 197-209

Williams GA (1993a) The relationship between herbivorous molluscs and algae on moderately exposed Hong Kong shores. In: Morton B (ed) Proceedings of the First International Conference on the Marine Biology of Hong Kong and the South China Sea. Hong Kong University Press, Hong Kong, p 459-469

Williams GA (1993b) Seasonal variation in algal species richness and abundance in the presence of molluscan herbivores on a tropical rocky shore. J Exp Mar Biol Ecol 167: 261-275

Williams GA (1994) The relationship between shade and molluscan grazing in structuring communities on a moderately-exposed tropical rocky shore. J Exp Mar Biol Ecol 178:79-95

Williams GA, Morritt D (1995) Habitat partitioning and thermal tolerance in a tropical limpet, Cellana grata. Mar Ecol Prog Ser 124:89-103

Submitted: June 14, 1999; Accepted: February 8, 2000 Proofs received from author(s): August 15, 2000 